\title{
Critical Requirements for Nursing Practice in Rural Disasters Caused by Floods
}

\author{
Exigências críticas para a prática de enfermeiros em desastres rurais causados por inundações
}

Exigencias críticas para la práctica de enfermeros en desastres rurales causados por inundaciones

Robriane Prosdocimi Menegat' ORCID: 0000-0003-3550-7816

Regina Rigatto Witt' ORCID: 0000-0002-3893-2829

'Universidade Federal do Rio Grande do Sul. Porto Alegre, Rio Grande do Sul, Brasil

How to cite this article: Menegat RP, Witt RR. Critical Requirements for Nursing Practice in Rural Disasters Caused by Floods. Rev Bras Enferm. 2019;72(3):687-91. doi: http://dx.doi.org/10.1590/0034-7167-2017-0606

Corresponding Author:

Robriane Prosdocimi Menegat Email: robrianepm@hotmail.com

Submission: 09-05-2017 Approval: 02-24-2019

\section{ABSTRACT}

Objective: To identify critical requirements for nursing practice when responding to hydrological disasters in the rural area. Method: A descriptive, exploratory and qualitative study was developed. The Critical Incidents Technique was adopted. Twenty public health nurses who worked during the flood season in the years of 2014 and 2015 in a rural area in Southern Brazil were interviewed. Content analysis of the data was developed. Results: Critical requirements for nurses' practice were derived from the situations ( $n=78)$, critical behaviors $(n=98)$ and consequences to the population $(n=43)$ and to the nurses $(n=38)$ identified. Conclusion / Final considerations: Although the requirements could be related to the established international referential for nurses practice in disasters, some were described only in this study. They can contribute to the education and practice of nurses in primary health care, strengthening its capacity to face disaster situations by flood in the rural area.

Descriptors: Rural Nursing; Rural Population; Disasters; Floods; Public Health.

\section{RESUMO}

Objetivo: Identificar as exigências críticas para a prática de enfermeiros na resposta a desastres hidrológicos na área rural. Método: Estudo descritivo, exploratório e qualitativo. Adotou-se a Técnica de Incidentes Críticos. Foram entrevistados 20 enfermeiros de saúde pública que trabalharam na época das inundações nos anos de 2014 e 2015 em áreas rurais do sul do Brasil. Realizou-se a análise de conteúdo dos dados. Resultados: Os requisitos críticos para a prática dos enfermeiros se originaram das situações $(n=78)$, comportamentos críticos $(n=98)$ e consequências para a população $(n=43)$ e para os enfermeiros $(n=38)$ identificados. Conclusão: Embora os requisitos possam estar relacionados ao referencial internacional estabelecido para a prática de enfermeiros em desastres, alguns foram descritos apenas neste estudo. Eles podem contribuir para a educação e prática do enfermeiro na Atenção Primária à Saúde, fortalecendo sua capacidade de enfrentar situações de desastre por inundação rural.

Descritores: Enfermagem Rural; População Rural; Desastres; Inundação; Saúde Pública.

\section{RESUMEN}

Objetivo: Identificar las exigencias críticas para la práctica de enfermeros en la respuesta a desastres hidrológicos en áreas rurales. Método: Estudio descriptivo, exploratorio y cualitativo. Se adoptó la Técnica de Incidentes Críticos. Se entrevistó a 20 enfermeros de salud pública que trabajaron en la época de las inundaciones en los años 2014 y 2015 en áreas rurales del sur de Brasil. Se realizó el análisis de contenido de los datos. Resultados: Los requisitos críticos para la práctica de los enfermeros fueron originados de las situaciones ( $n=78)$, comportamientos críticos $(n=98)$ y consecuencias para la población $(n=43)$ y para los enfermeros $(n=38)$. Conclusión: Aunque las exigencias pueden estar relacionadas al referencial internacional establecido para la práctica de enfermeros en desastres, algunos sólo se describieron en este estudio. Pueden contribuir a la educación y práctica del enfermero en la atención primaria a la salud, fortaleciendo su capacidad en inundaciones.

Descriptores: Enfermería Rural; Población Rural; Desastres; Inundación; Salud Pública. 


\section{INTRODUCTION}

Disasters have drawn attention worldwide, because of the growth in their number and intensity, with social and economic consequences and human, material and environmental damage. With the largest share of natural disasters, hydrological disasters (floods and wet mass movements) caused 32 million victims and accounted for $46.5 \%$ of the total deaths $\ln 2013^{(1)}$

This situation has become worrying in the rural context because in this context natural resources are decreasing, poverty is frequent and conditions of access to health care services are precarious, affecting current global rural population health condition ${ }^{(2)}$ Brazil detects a great amount of floods and sliding ${ }^{(3)}$ which result in difficult access to public health services, caused by lack of transportation, due to poor conditions of the roads ${ }^{(4)}$

The unexpected transition after natural disasters by flood has impacted services routines, indicating the necessity of health professional preparation to mitigate their consequences and face emerging needs, with measures to preserve the environment and provide health care.

This type of disaster increases demands for health services, especially in primary health care ${ }^{(5)}$ In local rural communities, these services play an important role in the management of disasters caused by floods, especially for response and recovery.

The study of health professionals' performance in certain types of natural disasters has contributed to the identification of these requirements. Professional emergency preparedness skills among health professionals who worked during Hurricanes Katrina and Rita $^{(6)}$ and skills, knowledge, and attitudes required for nurses who worked after earthquake type disasters ${ }^{(7)}$ contribute to this knowledge.

Although, rural nurses are expected to demonstrate excellence in clinical decision making and function in a more independent, generalized fashion, in primary health care response depends on a synchronized action taken by a multidisciplinary team, from whom a series of requirements are expected, in order to ensure qualified and priority care.

\section{OBJECTIVE}

To identify nursing critical requirements when responding to hydrological disasters in the rural area.

\section{METHODOLOGY}

\section{Ethics approval}

Human research ethics approval number 1.455.248 was obtained from the Institutional Review Board of the Universidade Federal do Rio Grande do Sul. Written informed consent was obtained from all subjects.

\section{Study design}

A descriptive, exploratory, qualitative study was developed in 10 rural municipalities, located on the coast of the Uruguay River in Rio Grande do Sul, Brazil, an area frequently affected by storms and floods.

The critical incidents technique was adopted ${ }^{(8)}$ considering that it allows the researcher to derive the skills of a person based on the activities performed. The goals of the study, the questionnaire, the population and sample and the collection of critical incident data were determined according to the technique.

\section{Selection of panel members}

Participants were public health nurses with a direct or indirect role in providing care to the rural population in the response and recovery phases of the 2014 and 2015 hydrological disasters. The sample was selected intentionally, in order to obtain a representation from different locations and experiences.

\section{Data collection}

Data was collected through semi-structured interviews with twenty nurses. This number was considered sufficient, based on the theoretical saturation of the data and the objectives of the study.

Nurses were asked to provide a detailed report of a situation when health care was necessary after the floods of 2014 and 2015 , specifying exactly what the situation was, what was done, and what happened after that. A pre-test of the interview script was carried out with two primary health care nurses. The study period is from the beginning of the data collection in 2016 until the end of the writing of this manuscript in 2018.

\section{Data analysis}

Empirical data was recorded, transcribed in full and organized to identify significant narratives, groups and categories. Critical requirements for the work of the nurse were derived from the situations, critical behaviors and consequences identified.

Critical requirements were considered the series of behaviors, positive and negative performed by the nurses ${ }^{(8)}$

\section{RESULTS}

\section{Sample demographic characteristics}

Of the practicing nurses ( $n=20), 14$ worked as primary health care nurses and the others held positions as Coordinator of health programs $(n=3)$, Responsible for health surveillance $(n=2)$ and Psychosocial services $(n=1)$. They had been employed in their current positions for until 5 years $(n=7), 6$ to 10 years $(n=6)$, or more than 11 years $(n=7)$. Education background included specialization in Public health $(n=7)$, Primary health care $(n=5)$, and Emergency care $(n=2)$. Most of them $(n=16)$ referred previous experience in disaster situations.

\section{Critical incidents}

From the critical incidents ( $n=84), 78$ situations, 8 behaviors, 10 consequences to the population and 9 consequences to the nurses were identified. The most frequent and the number of times they were identified are shown in Table 1.

Other situations identified were isolated rural areas, life risk exposition, moving temporarily or permanently from their homes, lack of medication, wounds, dermatitis, infectious and respiratory infectious diseases, waterborne diseases, zoonosis and accidents with venomous animal, and garbage disposal. 
Table 1 - Critical incidents, situations, behaviors and consequences described by nurses. Porto Alegre, 2016

\begin{tabular}{|c|c|c|c|c|c|c|}
\hline \multirow{2}{*}{ Critical incidents } & \multicolumn{2}{|c|}{ Total } & \multicolumn{2}{|c|}{ Positive } & \multicolumn{2}{|c|}{ Negative } \\
\hline & $\mathbf{N}$ & $\%$ & $\mathbf{N}$ & $\%$ & $\mathbf{N}$ & $\%$ \\
\hline \multicolumn{7}{|l|}{ Situations } \\
\hline Loss of material goods & 12 & 15.38 & & & & \\
\hline Affected mental health & 10 & 12.82 & & & & \\
\hline Vulnerable population & 10 & 12.82 & & & & \\
\hline Others & 46 & 58.97 & & & & \\
\hline Total & 78 & 100 & & & & \\
\hline \multicolumn{7}{|l|}{ Nursing behaviours } \\
\hline Health education and surveillance & 22 & 22.45 & 21 & 21.43 & 1 & 1.02 \\
\hline Nursing care & 18 & 18.37 & 17 & 17.35 & 1 & 1.02 \\
\hline Health service management and organization of health teams & 16 & 16.33 & 14 & 14.28 & 2 & 2.04 \\
\hline Others & 42 & 42.74 & 36 & 36.72 & 6 & 6.12 \\
\hline Total & 98 & 100 & 88 & 89.78 & 10 & 10.22 \\
\hline \multicolumn{7}{|l|}{ Consequences to the nurses } \\
\hline Streamline problem solving with teamwork, discussion of situations and integrated actions & 6 & 15.79 & 6 & 15.79 & 0 & 0 \\
\hline Work process conditioned by availability of supplies & 8 & 21.05 & 5 & 13.16 & 3 & 7.89 \\
\hline Others & 24 & 63.15 & 7 & 18.42 & 17 & 44.73 \\
\hline Total & 38 & 100 & 18 & 47.37 & 20 & 52.62 \\
\hline \multicolumn{7}{|l|}{ Consequences to the population } \\
\hline Impacts to the health of the population & 9 & 20.93 & 7 & 16.28 & 2 & 4.65 \\
\hline Emotional instability & 7 & 16.28 & 0 & 0 & 7 & 16.28 \\
\hline Others & 27 & 62.79 & 16 & 37.2 & 11 & 30.57 \\
\hline Total & 43 & 100 & 23 & 52.48 & 20 & 51.50 \\
\hline
\end{tabular}

Nurses behaviors could be related to these situations. Actions towards the protection of those in life risk were identified as well as an effort to access remote areas. Nurses were also willing to help the population in need, providing and distributing essential goods, in collaboration with social assistance workforce.

Health care was provided through direct assistance on the treatment of wounds, immunizations, psychological support and reference as needed. Those patients in need of medication were also reached for the provision and maintenance of treatment. There was a concern on reaching those families in risk areas visiting them at home before the flood to alert them of the imminent disaster. During response, nurses kept visiting these families to provide education on the prevention of infectious and waterborne diseases.

\section{DISCUSSION}

Floods had a significant impact on the affected rural population. Consequences for local infrastructure, services, economy, and local society include total or partial impairment of agricultural and livestock activities, economic damage due to the total or partial destruction of property, homes and buildings and sources of income and labor ${ }^{(9)}$ as the interruption of the work of the fishermen in the affected area .

Emotional reactions had a very high frequency between the situations reported. Disorders and syndromes described in the literature include sleep disorders, insomnia, nightmares and repeated memories about the event, amnesia, difficulty concentrating, irritability and anger, anxiety, phobias, panic, depression, loss of appetite, fatigue, dizziness and Suicide ${ }^{(10)}$. In flooded areas anxiety, deliberate self-harm, depression/suicidal, situational crisis have been observed among females ${ }^{(11)}$. Interventions such as a strategy carried out in a rural area of Chile, after the earthquake and tsunami of February 27, 2010, was shown to be suitable for working with older people living in isolated territories. For this population, whose access to health services is reduced in a post-disaster context, this intervention strategy allowed the emergence and use as a resource the elements of one's own culture, and enhanced their local support networks ${ }^{(12)}$.

When caring of vulnerable populations, their propensity for the negative impacts of hazards and disasters, identifying the characteristics that increase or decrease their capacity to prepare for and respond to a disaster must be considered. Risks and potential losses have to be identified ${ }^{(13)}$.

The situation of having to evacuate is also very frequent during disasters. For those who have to leave their homes the experience is stressful, because of the expectation of returning to their properties. Those who did not evacuate faced months of living in wet and dusty conditions and with the prospect of being in the midst of empty properties. Either option causes an interruption in daily life ${ }^{(10)}$, as reported by the participants of this study, with repercussions on the health of the population, as occurred with hypertensive patients and with a pregnant woman, who started preterm labor. 
During floods, alterations in the cycles of vectors, hosts and reservoirs of diseases and in the forms of human environmental exposures, cause illnesses and diseases, including some signs and symptoms such as diarrhea and gastroenteritis, leptospirosis and conjunctivitis ${ }^{(9)}$. Acute respiratory diseases ${ }^{(10)}$ are also frequent as identified in this study.

Rapid needs assessment can assist health professionals in their practice. A frequency of up to $30 \%$ of cuts, perforation and abrasions were identified among the health consequences of the population in a flood disaster situation ${ }^{(11)}$, which explains the performance of nurses in this study in the treatment of injuries, wounds and dermatitis. This assessment can be carried out by means of a risk mapping developed in conjunction with community health agents, a risk map with risk areas for flooding and signaling of places where pregnant women, hypertensives, the elderly (vulnerable population), as reported by the participants of this study.

For nurses, the concern in the phase of response was mainly the provision of essential goods, such as shelter, food, drinking water, and the prophylaxis of water-borne diseases. A good relationship and knowledge of the population and its territory facilitated the response, although difficulties, such as the feeling of powerlessness and perceived limitation of their practice were reported.

Several organizations such as the municipal secretariats of construction, health, agriculture, environment, the army, the civil defense, a military brigade and firefighters were reported to have participated in the response. This effort though was found not to be as coordinated as wished by the participants. A feeling that various authorities and particularly the local council had reacted badly after a disaster by flood has been described before ${ }^{(14)}$, indicating the need of including the integration of response organizations in the preparation of a disaster plan.

Nurses also reported the lack of guidelines to support their practice. Activities in which they reported the need of this support were the educational when handling food, water, cleaning and hygiene habits were taught. Health education was directed to the team to prepare them to develop educational activities in the community. Meetings at the health services, at the homes of those affected and at the shelters were hold. Some of these activities were performed by nurses during an epidemics to provide health information (90\%), administer vaccinations (82\%), and triage (74\%) neighbors/friends from home ${ }^{(15)}$.

\section{Study limitations}

Some limitations of this study, related to the critical incidents technique were the use of facts that occurred one or two years before data collection, since we ignore on what extension psychological impact at the time of the disaster could have interfered in the nurses' ability to remember the facts in full. In addition, we had the limitation that some nurses who worked during the floods of 2014 and 2015, did not work in the cities surveyed in the data collection period.

\section{Contributions for nursing, health and public policies}

The study contributes to a greater visibility of public health nurses' practice in the response and recovery phases of a disaster caused by floods in rural area. The knowledge of the situations, nurses' behaviors and consequences identified can subsidize Primary Health Care teams to better prepare and respond to disasters caused by floods, contributing for the National Emergency Policy in Brazil. International disaster' policies can also benefit from these critical requirements, aggregating to the preparation and practice of health professionals so that they can learn to deal and provide adequate attention to the rural population in a disaster. Nurses workers in municipalities located on the riverside will benefit with this study.

\section{FINAL CONSIDERATIONS}

This study identified critical requirements for the nurse when caring of rural population after a disaster by flood, based on the experiences of nurses working in Primary Health Care. Situations, behaviors and consequences for the population and for the nurses, evidenced an interrelation between these components.

Some critical behaviors could be related to one situation, others to more than one and others to many of the situations described.

The situations, behaviors and consequences reported by the nurses could be related to those identified in other realities in which flood disasters are frequent. This type of evidence corroborates to the recognition of incidents that take place in a disaster by flood and contribute to the mitigation of its consequences and to elaborate new strategies of prevention and preparation.

The critical requirements identified contribute to improve and streamline nurses' actions, positively influencing their practice and the health of the rural population. Recommendations for the postflood context include the possibility and the duty of the nurse to develop guidelines to prevent disease and promote health care.

Critical requirements, translated into situations, consequences and behaviors can constitute a subsidy and referential for the preparation and performance of nurses in primary care, in view of the increase in the occurrence of flood disasters, making it possible to rethink their practices to the affected population or in areas at risk.

\section{ACKNOWLEDGEMENTS}

Coordenação de Aperfeiçoamento de Pessoal de Nivel Superior/CAPES of Brazil for financial support.

\section{REFERENCES}

1. Guha-Sapir D, Hoyois PH, Below R. Annual Disaster Statistical Review 2015: the numbers and trends. Brussels: CRED; 2016.

2. United Nations. World Urbanization Prospects The 2014 Revision. Highlights [Internet]. New Yotk: United Nations; 2014 [cited 2016 May 10]. Available from: http://esa.un.org/unpd/wup/publications/files/wup2014-highlights.pdf 
3. Ministério da Integração Nacional (BR), Secretaria Nacional de Defesa Civil. Centro Nacional de Gerenciamento de Riscos e Desastres. Anuário Brasileiro de Desastres Naturais. Brasília: CENAD; 2012.

4. Fernandes GCM, Boehs AE. Routine healthcare for families in transition after a natural disaster. Rev Lat Am Enferm [Internet]. 2013 [cited 2016 May 3]:21(4):982-9. Available from: http://dx.doi.org/10.1590/S0104-11692013000400021

5. Van Minh H, Tuan Anh T, Rocklöv J, Bao Giang K, Trang le Q, Sahlen KG, et al. Primary healthcare system capacities for responding to storm and flood-related health problems: a case study from a rural district in central vietnam. Glob Health Action [Internet]. 2014 [cited 2019 Mar 13];7:23007. Available from: http://dx.doi.org/10.3402/gha.v7.23007

6. Slepski L. Emergency preparedness and professional competency among health care providers during hurricanes katrina and rita: pilot study results. Disaster Manag Response [Internet]. 2007 [cited 2019 Mar 13];5(4):99-110. Available from: http://dx.doi.org/10.1016/j. dmr.2007.08.001

7. Yan YE, Turale S, Stone T, Petrini M. Disaster nursing skills, knowledge and attitudes required in earthquake relief: implications for nursing education. Int Nurs Rev [Internet]. 2015 [cited 2019 Mar 13];62(3):351-59. Available from: https://doi.org/10.1111/inr.12175

8. Schluter J, Seaton P, Chaboyer W. Critical incident technique: a user's guide for nurse researchers. J Adv Nurs [Internet]. 2008 [cited 2019 Mar 13];61(1):107-14. Available from: https://doi.org/10.1111/j.1365-2648.2007.04490.x

9. Freitas $\mathrm{CM}$, Ximenes EF. [Floods and Public Health - a review of the recent scientific literature on the causes, consequences and responses to prevention and mitigation]. Ciênc Saúde Colet [Internet]. 2012 [cited 2016 Oct 5];17(6):1601-1615. Available from: http://dx.doi. org/10.1590/S1413-81232012000600023 Portuguese

10. Tapsell SM, Penning-Rowsell EC, Tunstall SM, Wilson TL. Vulnerability to flooding: health and social dimensions. Philos Trans A Math Phys Eng Sci [Internet] 2002 [cited 2019 Mar 13];360(1796):1511-25. Available from: http://dx.doi.org/10.1098/rsta.2002.1013

11. Sahni V, Scott AN, Beliveau M, Varughese M, Dover DC, Talbot J. Public health surveillance response following the southern Alberta floods, 2013. Can J Public Health [Internet]. 2016 [cited 2019 Mar 13];107(2):e142-48. Available from: http://dx.doi.org/10.17269/cjph.107.5188

12. Osorio-Parraguez P, Espinoza A. [Salud mental en desastres naturales: estrategias interventivas con adultos mayores en sectores rurales de chile]. Glob Health Promot [Internet]. 2016 [cited 2019 Mar 13];23(2):84-91. Available from: https://doi.org/10.1177/1757975914566890 Spanish.

13. Noal DS, Vicente LN, Weintraub ACAM, Knobloch F. A atuação do psicólogo em situações de desastres: algumas considerações baseadas em experiências de intervenção. Rev Entre Linhas [Internet]. 2013[cited 2017 Jan 5]:13(62):4-5. Available from: http://www.crprs.org.br/upload/ edicao/arquivo57.pdf

14. Quinlisk P, Jones MJ, Bostick N, Subbarao I. Results of rapid needs assessments in rural and urban iowa following large-scale flooding events in 2008. Disaster Med Public Health Prep [Internet]. 2008 [cited 2019 Mar 13];5(4):287-292. Available from: http://dx.doi.org/10.1001/ dmp.2011.82

15. Bell MA, Dake JA, Price JH, Jordan TR, Rega P. A national survey of emergency nurses and avian influenza threat. J Emerg Nurs [Internet]. 2014 [cited 2019 Mar 13];40(3):212-7. Available from: http://dx.doi.org/10.1016/j.jen.2012.05.005 